\title{
PELVIC LYMPHOSCINTIGRAPHY: CONTRIBUTION TO THE PREOPERATIVE STAGING OF RECTAL CANCER
}

\author{
José Hyppolito da Silva
}

RHCFAP/3069

SILVA JH da - Pelvic lymphoscintigraphy: contribution to the preoperative staging of rectal cancer. Rev. Hosp. Clín. Fac. Med. S. Paulo 57 (2):55-62, 2002.

PURPOSE: Preservation of the anal sphincter in surgery for cancer of the distal rectum in an attempt to avoid colostomy has been a main concern of colorectal surgeons. Various proposed procedures contradict oncological principles, especially with respect to pelvic lymphadenectomy. Therefore, prior knowledge of pelvic lymph node involvement is an important factor in choosing the operative technique, i.e., radical or conservative resection. Introduction of ultrasound, computerized tomography, and magnetic resonance have made preoperative study of the area possible. Nevertheless, these resources offer information of an anatomical nature only. Lymphoscintigraphy enables the morphological and functional evaluation of the pelvic area and contributes toward complementing the data obtained with the other imaging techniques. The objective of this prospective study is twofold: to standardize the lymphoscintigraphy technique and to use it to differentiate patients with rectal cancer from those with other coloproctologic diseases.

CASUISTIC AND METHODS: Sixty patients with various coloproctologic diseases were studied prospectively. Ages ranged from 21 to 96 years (average, 51 and median, 55 years). Twenty-six patients were male and 34 were female. Thirty patients had carcinoma of the distal rectum as diagnosed by proctologic and anatomic-pathologic examinations, 20 patients had hemorrhoids, 5 had chagasic megacolon, 2 had diverticular disease, 2 had neoplasm of the right colon, and 1 had ulcerative colitis as diagnosed by proctologic exam and/or enema. The lymphoscintigraphy method consisted of injecting $0.25 \mathrm{~mL}$ of a dextran solution marked with radioactive technetium-99m into the right and left sides of the perianal region and obtaining images with a gamma camera. The results were analyzed statistically with a confidence level of $95 \%(P<.05)$ using the following statistical techniques: arithmetic and medium average, Fisher exact test, chi-square test corrected for continuity according to Yates, and distribution tables for the number of patients.

RESULTS: In rectal cancer, the tracer progresses unilaterally or is absent; in other patients, the progress of the tracer is bilateral and symmetrical, although its progress may be slow. Statistical tests showed with high significance that the agreement index between the clinical diagnosis and the result of the lymphoscintigraphic exam was $93 \%$.

CONCLUSIONS: Lymphoscintigraphy is a standardized, painless, and harmless test that can be performed in all cases; it differentiates patients with rectal cancer from those with other coloproctological diseases.

DESCRIPTORS: Lymphoscintigraphy. Rectal cancer. Lymph nodes. Staging of rectal cancer.

When the possibility of cure is sought, treatment of cancer of the rectum is surgical. The operation of choice is abdominoperineal resection when the lesion is located in the distal third, with consequent definitive colostomy. This procedure is based in oncological principles of resection of the segment with the lesion and of the tissues corresponding to the areas of lymphatic propagation.
In spite of the radical nature of this operation, in some cases surgeons perform techniques that preserve the sphincters, with re-establishment of transit through a colorectal or colo-anal anastomosis. Often, examination of the operative specimen reveals an absence

From the Department of Gastroenterology, Hospital das Clínicas, Faculty of Medicine, University of São Paulo. of involved lymph nodes, so there is greater incentive for preservation of the sphincters. It is obvious, therefore, that the prior knowledge of the status of lymph nodal involvement is of fundamental importance in the choice of the surgical procedure, i.e., radical or conservative resection.

Until recently, evaluation of the pelvic lymph nodal chain was only possible after the operation and consisted 
of the anatomic-pathologic study of the excised specimen. This kind of staging, however, is not efficient, since lymphadenectomy, for several reasons, can be incomplete, and the histological examination does not always reveal the complete picture.

Introduction of ultrasound, computerized tomography, and magnetic resonance has enabled the possibility of identifying and analyzing the anatomical aspects of the pelvic lymph nodes. These methods are being continuously improved through the introduction of new equipment and establishment of patterns of normality.

Scintigraphy of the lymph nodes, with the great technological development in the last decades and the use of new radioisotopes, has not only provided anatomical information from regions not reached by the conventional lymphography, but also function information. Pelvic lymphoscintigraphy provides both morphological and functional information of the lymphatic system of that area, complementing and refining the information obtained with the previously mentioned techniques.

Thus, better preoperative diagnosis will provide understanding of the physiopathology of the malignant disease, its dissemination, and consequently, orient the surgical treatment of rectal cancer. A range of clinical cases exists, varying from those of lesser complexity with localized lesions, in which sphincter preservation is possible, to those of extensive lymph nodal involvement, which require large resections and supplementary therapy.

The objective of this investigation was to standardize pelvic lymphoscintigraphy, to evaluate its use for establishing differentiation between patients with rectal cancer and those with other coloproctologic diseases, and to verify the validity of preoperative evaluation of the involvement of lymph nodes in cases of rectal cancer.

\section{SURVEY OF THE LITERATURE}

In spite of the importance of the lymphatic system, current technology is still insufficient for its complete study. Although conventional lymphography provides good resolution for certain anatomical areas, the method cannot be applied in the colorectal region because of technical limitations. This fact stimulated the search for alternative procedures to fill that gap.

The employment of radioactive isotopes in the study of lymph nodal chains began with the objective of using them in the selective irradiation of metastasis along the pathways of lymphatic propagation and of lymph nodes. Based on the fact that colloids injected in the interstitial space are collected by phagocytes and transported through the lymphatic system to regional lymph nodes where they are then stored and concentrated, the behavior of radioactive gold colloid was studied in animals ${ }^{1}$. However, radioactive gold has the disadvantage of provoking radiation discharge in the region of injection caused by its long half-life and by its emission of beta rays, rendering its clinical application unfeasible.

A radioisotope without the limitations of radioactive gold was sought. Technetium-99m (isotope 99 and metastable) was introduced, which has a short half-life and emits gamma rays, making it ideal for generating images ${ }^{2}$. These images were made possible by the subsequent development of the scintigraphic equipment for reception of gamma rays.

This new methodology for studying the lymphatic chain is superior to conventional lymphography for the following reasons: first, it is possible to use a reduced volume of the drugs and to use a saline vehicle; second, the lymph nodal reception of the particles is a function of the normal lymphatic flow and of phagocytosis; and finally, dissection and cannulation of the vessels and use of an infusion pump are not necessary.

With the employment of new radioisotopes and modern imaging devices, the lymphoscintigraphy method has been shown to be reproducible and noninvasive, and it correlates well with the anatomic pattern of lymph node distribution ${ }^{3}$.

It has been confirmed that in the pelvic area, lymphatic drainage occurs via the vessels that follow the inferior hemorrhoid vein and that terminate in a complex of lymph nodes known as the iliopelvic plexus. The ideal place for injection of radioactive colloids is in the interstitial tissue of the ischiorectal fossa ${ }^{4}$.

The results obtained with the colloids, however, were not regular because of the variable size of the colloidal particles, which reduced the reproducibility of the method. When radiolabeled dextran, labeled with technetium- $99 \mathrm{~m}$ was introduced and tested, it showed promise as a marking agent for lymphoscintigraphy ${ }^{5,6}$. The dextran marked by the technetium- $99 \mathrm{~m}$ and injected in the interstitial space is drained by the regional lymphatic system, reaching the blood through the thoracic duct.

As soon as the new methodology was introduced, it was natural that specialists would be interested in testing its usefulness in the diagnosis of colorectal cancer. Several papers appeared in the literature about this subject $^{4,7-14}$. These studies showed that preoperative diagnosis of tumors belonging to the $\mathrm{C} 1$ and $\mathrm{C} 2$ Astler-Coller classification $^{15}$, that is, with involved lymph nodes, was possible through lymphoscintigraphy ${ }^{8}$. Castro et al. ${ }^{9}$ concluded that the method assesses morphology and function, is simple, innocuous, and painless, and that it seems to yield results that agree with the histological exam of the carcinoma 
of the rectum. Arnaud et al. ${ }^{14}$ concluded that lymphoscintigraphy is the only useful method for evaluating lymphatic dissemination of rectal cancer.

\section{PATIENTS AND METHODS}

Sixty patients were studied prospectively. Ages ranged from 21 to 96 years, with an average of 51 and median of 55 years. Twenty-six were male and 34 were female.

The patients had varous coloproctologic diseases, as follows: cancer of distal rectum diagnosed by proctologic and anatomic-pathologic examinations (30 patients); hemorrhoids (20 patients); chagasic megacolon (5 patients); diverticular disease (2 patients); neoplasm of the right colon (2 patients); and ulcerative colitis diagnosed by proctologic exam and/or enema (1 patient).

All patients were informed of the nature of the exam and that the result obtained might not bring benefit and/ or elucidation concerning their disease. The proposal for the clinical investigation was submitted to and approved by the Commission of Ethics.

All patients underwent the exams in agreement with the routine of the Service of Radioisotopes.

The patients were placed in left lateral position with exposure of the anal area and underwent antisepsis. The dextran (Dx 70.000) labeled with technetium-99m (99m Tc), was diluted to obtain $1 \mathrm{mCi}$ in $0.5 \mathrm{~mL}$. That solution was injected in the subcutaneous anal area within $1 \mathrm{~cm}$ of the anal sphincter in the amount of $0.25 \mathrm{~mL}$ on each side, in positions corresponding to the right and left lateral parts.

The patients came back to the Service after 3, 6, and 24 hours for images taken with a gamma camera (Siemens, model Orbiter 75 or LEM), with collimation for high resolution and adjusted for the detection of $95 \%$ of the photons emitted in the energy spectrum corresponding to the isotope chosen. The results were logged for subsequent reading by a specialist who had no previous knowledge of the cases.

The patients were classified into 4 groups, according to the distribution of the marker:

Group I - normal and symmetrical progression (Fig. 1)

Group II - retarded progression (Fig. 2)
Group III - asymmetric progression (Fig. 3)

Group IV - absence of progression (Fig. 4)

Normal and symmetrical progression is characterized by the bilateral and symmetrical visualization of the image of the marker. Retarded progression conserves the symmetry, but the progression of the marker is slow. Asymmetric progression is unilateral; the marker not seen on the opposite

Figure 1 - Normal and symmetrical progression.
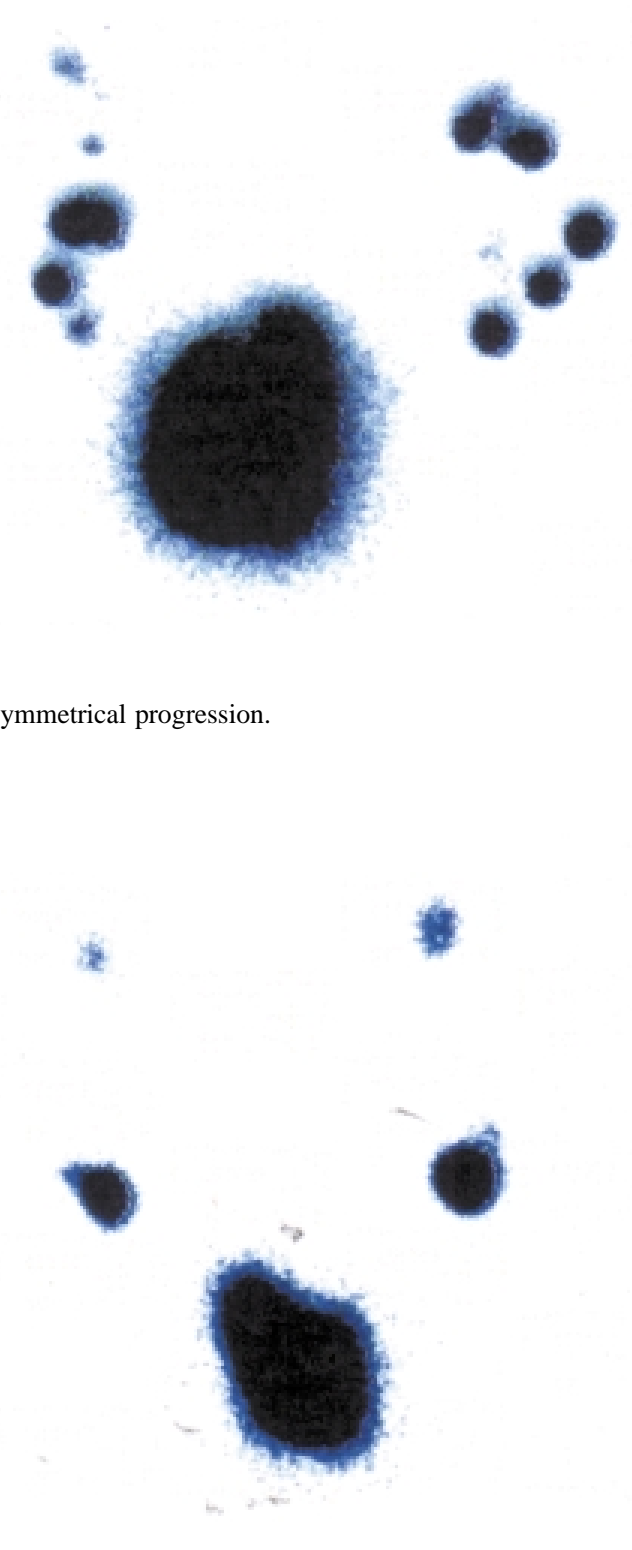

Figure 2 - Retarded progression. 


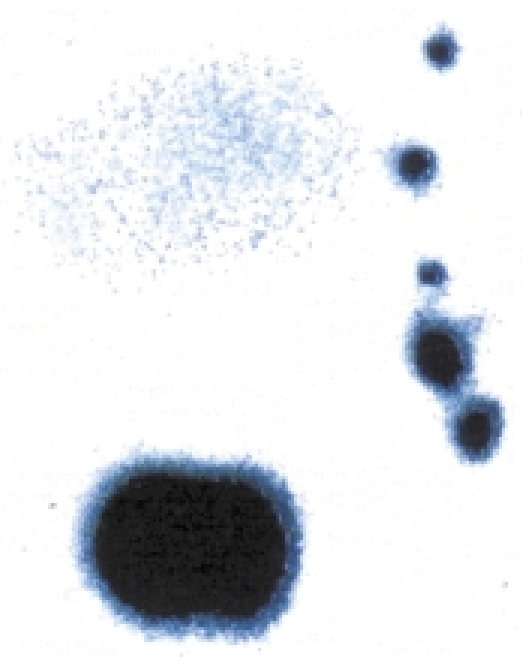

Figure 3 - Asymmetric progression.

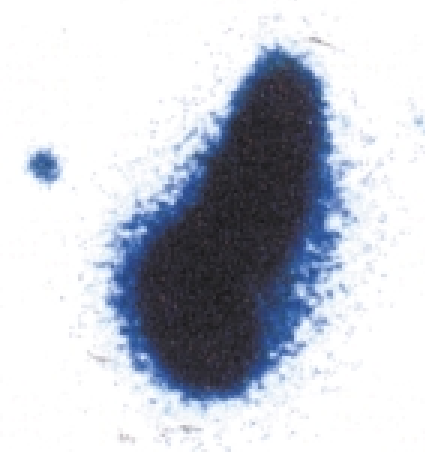

Figure 4 - Absence of progression.

side. Finally, in the absence of progression, the marker stays static, and it occasionally marks the presence of one or more lymph nodes.

The results were statistically analyzed with the level of confidence set at $95 \%(P<.05)$ using the following techniques:

1. Arithmetic and median average

2. Fisher exact test

3. Chi-square test corrected for continuity, according to Yates
4. Distribution tables for the number of patients

\section{RESULTS}

The exam was well tolerated by all patients who experienced no local or systemic reactions. There was no reference to pain.

Although images on films obtained at 3, 6, and 24 hours had few differ- ences, the analysis of them contributed to the understanding of the contribution of temporary registration in the dynamic evaluation of the progression.

Groups I and II had functional and anatomical integrity; therefore, they are considered negative for compromised lymph nodes. Groups III and IV had an absence of the marker unilaterally or bilaterally, characterizing compromise of the lymph node chain. The correlation of the lymphoscintigraphic classification and the diagnosed disease is shown in table 1 .

For patients with cancer of the rectum, the classification distribution was as follows: group I, 1 case; group II, 1 case; group III, 22 cases; group IV, 6 cases. Of the total of 30 cases, 2 belonged to the groups I and II and 28 to the groups III and IV (Table 2).

For patients with other colorectal diseases, 18 presented normal and symmetrical progression (group I); 10 were classified in group II and 2 in group IV. Of the total, 28 belonged to groups I and II and 2 to group IV (Table 2).

The analysis of this table allows verification that 2 patients with cancer of the rectum belonged to groups I and II and 28 to groups III and IV. Inversely, for patients with other colorectal diseases, 28 belonged to groups I and II, and 2 to groups III and IV (Table 3).

Therefore, the lymphoscintigraphic exam produced indexes that were highly correlated with the diagnosis of disease, which was demonstrated with high significance by several statistical tests. We can affirm that the agreement index between the clinical diagnosis and the result of the lymphoscintigraphic exam is $93 \%$.

\section{DISCUSSION}

Cancer of the large intestine is diagnosed frequently, especially in west- 
Table 1 - Distribution of lymphoscintigraphic classification and diagnosed disease.

\begin{tabular}{lrrrrr}
\hline & \multicolumn{5}{c}{ Lymphoscintigraphy (Groups) } \\
Diseases & I & II & III & IV & Total \\
\hline Cancer of rectum & 1 & 1 & 22 & 6 & 30 \\
Hemorrhoids & 13 & 6 & 0 & 1 & 20 \\
Megacolon & 4 & 1 & 0 & 0 & 5 \\
Diverticular disease & 0 & 1 & 0 & 1 & 2 \\
Cancer of colon & 0 & 2 & 0 & 0 & 2 \\
Ulcerative colitis & 1 & 0 & 0 & 0 & 1 \\
\hline Total & 19 & 11 & 22 & 8 & 60 \\
\hline
\end{tabular}

Table 2 - Distribution of the patients in agreement with the lymphoscintigraphic classification and the 2 groups of diseases.

\begin{tabular}{lrrrrrr}
\hline & \multicolumn{4}{c}{ Lymphoscintigraphy (Groups) } \\
Diseases & I & II & III & IV & Total \\
\hline Cancer of rectum & 1 & 1 & 22 & 6 & 30 \\
Several diseases & 18 & 10 & 0 & 2 & 30 \\
\hline Total & 19 & 11 & 22 & 8 & 60 \\
\hline
\end{tabular}

Table 3 - Distribution of the patients and respective percents in agreement with lymphoscintigraphics pairs and the 2 groups of diseases. Chi square tests corrected for continuity according to Yates and Fisher exact tests.

\begin{tabular}{lrrrrr}
\hline \multirow{2}{*}{ Diseases } & \multicolumn{2}{c}{ Lymphoscintigraphy (Groups) } & & \\
I and II & III and IV & Total & $X^{2}$ (Yates) & Fisher exact test \\
\hline Cancer of the rectum & $2(6.7 \%)$ & $28(93.3 \%)$ & 30 & $=41.67$ & $P<0.00000001$ \\
Other colorectal diseases & $28(93.3 \%)$ & $2(6.7 \%)$ & 30 & & $P<0.00000001$ \\
\hline Total & 30 & 30 & 60 & & \\
\hline
\end{tabular}

ern countries. Results collected at laboratories of pathological anatomy in Brazil during the period from 1976 to 1980 revealed that cancer of the large intestine that includes the anal canal is the fourth most frequently occurring cancer in men and the third in women, with exclusion of the cutaneous tumors ${ }^{16}$. In the United States of America, the American Society of Cancer estimated that 157,500 new cases of cancer of the large intestine were diagnosed in $1991^{17}$.

Rectal cancer corresponds to $50 \%$ of the malignant tumors of the large intestine, and when added to the cases of cancer of the rectal-sigmoid junction comprise $60 \%$ to $70 \%$. Concerning the regional topographic aspect, the lesions are located in the proximal, medial, and distal thirds, respectively, 11-15 $\mathrm{cm}, 7-11 \mathrm{~cm}$, and less than $7 \mathrm{~cm}$ from the anal margin ${ }^{18}$.

Surgical treatment of the lesion provides the best results when the possibility of cure of the disease is sought. Radiotherapy, chemotherapy, and immunotherapy, isolated or associated, are used as adjuvant methods; among them, radiotherapy deserves special prominence for preventing or reducing local recurrence, a frequent and feared occurrence, because of the tiresome symptoms and potential for fatal outcome.

Anatomic studies of lymphatic drainage from rectal tumors have shown that for the tumors located in the proximal third, drainage occurs cranially and for those located in the medial and distal third, drainage occurs cranially and laterally.

The current tendency to choose conservative surgery for the lesions located in the proximal and medial thirds and radical surgery for lesions in the third distal of the colon is justified. Therefore, the preoperative staging of cancer of the rectum is of fundamental importance, because it enables the appropriate choice of surgical technique and indicates the appropriate complementary therapy, usually concerning radiotherapy.

Clinicians seek preoperative knowledge of the local conditions of the tumor, such as size, site, mobility, etc., degree of the penetration into the wall, histologic characteristics, the involvement of the lymph nodes and of the neighboring organs, and of the presence metastasis.

The proctologic exam provides a local evaluation of the lesion. However, it provides little information concerning the degree of parietal penetration and less concerning the state of the lymph nodes; the same can be said regarding the opaque enema. Until recently, only lung metastases were diagnosed through thorax X-ray.

Modern imaging methods, such as ultrasound, computerized tomography, and magnetic resonance yield more information. In fact, conventional ultrasound allows the diagnosis of hepatic metastases, compressions and infiltration in the bladder, ureteral dilatations, etc.; endo-rectal ultrasound reveals the degree of parietal penetration and the presence of compromised lymph nodes; and tomography and resonance reveal parietal penetration and extrarectal tumors, just to mention the known discoveries. Those methods, however, just supply a morphologic view of the disease.

Pelvic lymph nodes cannot be evaluated by palpation, since size is not 
a reliable indicator of the presence of a tumor; an increased size can be caused by the presence of infection, and a node of normal size can contain neoplastic tissue. Even lymphadenectomy and histologic exam can yield incomplete information on the progression of the cancer. In summary, staging of rectal cancer using currently available modes is precarious ${ }^{10}$.

The preoperative evaluation of the lymph nodes of the pelvic space allows the staging of the rectal neoplasm, potentiating the definition of the patient's risk group and the identification of those patients who are candidates for adjuvant therapy or conservative local resection. Therefore, the previous diagnosis of the extent of involvement of the lymph nodes is of the highest importance for successful treatment.

The size of the lymph nodes is considered the most important parameter for defining whether or not there is lymph node involvement. However, none of the imaging methods are conclusive, because small lymph nodes can contain nests of tumor cells, and the big ones be just inflammatory. We concluded that the available imaging techniques do not provide a better definition of the extent of involvement of the lymph nodes. As consequence, was natural to search for a new method that could solve the problem.

In a study of patients with malignant tumors of the lesser pelvis using the conventional lymphography with the objective of planning the treatment, it was verified that the method shows the external and the common iliac network but does not show the internal iliac network ${ }^{19}$.

The decline of the lymphography after the advent of the computerized tomography has been reported. The decline was attributed to the invasiveness of the exam, to the technical difficulties, to the morbidity it caused, and primarily, to the preference of the radiologists and of the doctors ${ }^{20}$.
Pelvic lymphoscintigraphy, which is a simple procedure, allows the study of the areas not available to the lymphographic method. Based on the extensive experience obtained in the mammary area, we began to investigate the rectal region, utilizing the expertise with the technology and the interpretation of the results. Several concepts resulted regarding the function and anatomy and regarding the establishment of the local patterns.

Although the ischio-rectal fossa was chosen as the ideal place of interstitial injection of the radioisotope to best mark the iliopelvic lymph nodes in animal studies ${ }^{4}$, it was demonstrated that lymphatic drainage of the large intestine could be delineated after the injection of a colloid radioisotope into the mucous membrane ${ }^{7}$.

Regarding colloids, the lack of reproducibility caused by the variable dimensions of the particles induced a search for another vehicle to carry the radioisotope. Dextran, as mentioned previously, has known molecular weight (70 000), is soluble in the lymphatic fluid and does not cross the capillary membrane after interstitial injection. Regarding the nuclide, technetium- $99 \mathrm{~m}$ is readily available, is relatively inexpensive, is of low radioactivity, emits gamma radiation, is metastable, and has a half-life of 6 hours $^{21}$.

After traversing the lymphatic system, the particles not captured reach the venous system to be phagocytized by the reticulo-endothelial cells of the liver; therefore, hepatic visualization indicates an intact lymphatic-venous drainage system. Absence of hepatic visualization after 24 hours indicates obstruction of that system.

Therefore, under normal conditions, the technetium 99m-labeled tracer will be distributed evenly along all the lymph node groups, which will be well marked and homogeneous. If metastases are present, the tumor blocks the lymphatic flow, and the presence of the radiolabel will be reduced or absent $\mathrm{t}^{22}$. Blockade of the flow would also exist in patients with rectal neoplasm that is independent of the lymph nodal involvement though mechanisms still not established ${ }^{23}$.

Since we understood the basic principles of the lymphoscintigraphy and the results obtained under normal and pathological conditions, we were able to assess the credibility and reproducibility of the method in a study of the internal mammary lymph nodes of 140 patients, repeated at intervals of 3 days to 3 weeks; good correlation was found in $94 \%$ of the cases ${ }^{3}$. Lymphoscintigraphy has been found to be a reproducible and non-invasive technique ${ }^{24}$, and in a study of the network of the internal mammary lymph nodes, it was concluded that the method could have diagnostic value regarding neoplastic involvement of the lymph nodes ${ }^{25}$.

In this study, the parameters were 1) the progression of the marker in the lymphatic chain and 2) correlation of progression type with the type of pathology.

Basically, the 4 modalities of results relate to the function of the pelvic lymphatic chain. Normal and symmetrical progression and retarded bilateral progression were considered representative of normality, and asymmetry and absence of visualization were considered representative of abnormality. Twenty-eight of 30 cases of abnormal results occurred in patients with rectal neoplasm, and 28 of 30 normal results occurred in patients with nonneoplastic disease.

No objective explanation was possible for the false results in the 2 patients with non-neoplastic disease; one of them was elderly, and although there is a report of decreased lymph nodal activity with the age ${ }^{26}$, our cohort included a patient of advanced age who presented normal progression. The only possible explanation for those two cases is a decrease of the level of re- 
ceptivity of the lymph nodes ${ }^{7,27}$. Similarly, we cannot explain the false results for the 2 patients with rectal neoplasm. The possibility of the existence of parallel and normal adjacent chains to those blocked by tumor was considered $^{8}$.

Bucci et al have noted the importance of rectal lymphoscintigraphy for supplying preoperative information on the lymph nodes, facilitating the correct selection of the surgical technique to be used ${ }^{8}$.

Feigen et al reported that preoperative evaluation by the lymphoscintigraphy method of lymph nodal involvement in the rectal cancer in $17 \mathrm{pa}-$ tients had a sensitivity of $75 \%$, a specificity of $46 \%$, and an accuracy of $53 \%{ }^{10}$.

Kanaev et al reported that the correlation of the results of lymphoscintigraphy with the anatomopathology in cases of rectal cancer had a sensitivity of $96 \%$, a specificity of $65 \%$, and an accuracy of $80 \%$. Correct diagnosis of metastasis was made in $73 \%$, while absence of metastasis was confirmed in $94 \%{ }^{12}$.

Endoscopic lymphoscintigraphy of the lymphatic dissemination of the rectal cancer had a sensitivity of $85 \%$, a specificity of $68 \%$, and accuracy of $76 \%$, a positive predictive value of $71 \%$ and a negative predictive value of $83 \%{ }^{14}$. Arnaud et al. reported that endoscopic lymphoscintigraphy has value in patient selection for local resection of rectal tumors and to evaluate the effects of the preoperative radiotherapy ${ }^{28}$.

In our study, the agreement index between the clinical diagnosis and the result of the lymphoscintigraphic exam was $93 \%$, a result that was highly statistically significant. Pelvic lymphoscintigraphy reveals information that al- lows the evaluation of the functional state of the lymph nodes. These results have stimulated the desire to continue the work. Among the lines of suggested studies, we propose to compare the results of lymphoscintigraphy with other imaging methods and to repeat the exam after treatment with radiation and chemotherapy.

\section{CONCLUSIONS}

The analysis of the results lead to the conclusions that pelvic lymphoscintigraphy can be a standardized exam, is feasible in all suitable cases, is painless and innocuous; differentiates between patients with rectal cancer and those with non-neoplastic coloproctological diseases, with an agreement index with the clinical diagnosis of $93 \%$.
SILVA JH da - Linfocintilografia pélvica: contribuição ao estadiamento pré-operatório do câncer retal. Rev. Hosp. Clín. Fac. Med. S. Paulo 57 (2):55-62, 2002.

PROPÓSITO: A preservação do aparelho esfincteriano na cirurgia do câncer do reto distal tem sido objeto de preocupação dos cirurgiões, no sentido de se evitar a feitura de colostomia. Inúmeros procedimentos têm sido propostos, porém, esbarram nos princípios oncológicos de radicalidade da operação, mormente no que diz respeito ao esvaziamento ganglionar do espaço pélvico. O conhecimento prévio desse compartimento constitui, portanto, fator de fundamental importância na escolha do método cirúrgico, amputativo ou conservador. A introdução do ultrassom, da tomografia computado- rizada e da ressonância magnética possibilitou o estudo pré-operatório da região, porém, oferece somente informações de natureza anatômica. A linfocintilografia objetiva o estudo morfo-funcional desse espaço e contribui para complementar os dados obtidos com os exames citados. O objetivo deste trabalho é a padronização do método linfocintilográfico e estabelecer a diferença em portadores de câncer do reto e de outras afecções coloproctológicas.

CASUÍSTICA E MÉTODOS: O estudo foi prospectivo e incluiu 60 doentes com várias doenças coloproctológicas. Trinta eram portadores de câncer do reto e os restantes de outras enfermidades colo-retais. A idade variou de 21 a 96 anos de idade sendo a média de 51 e a mediana de 55 . Vinte e seis eram do sexo masculino e 34 do feminino. Os doentes eram portadores de câncer do reto distal ( 30 doentes ) diagnosticado por exame proctológico e anatomopatológico, cujo resultado revelou adenocarcinoma; hemorróidas (20 doentes); megacólon chagásico (cinco doentes); doença diverticular (dois doentes); câncer do cólon direito (dois doentes); retocolite ulcerativa (um doente) diagnosticadas por exame proctológico e/ou enema baritado. O método consistiu na injeção de 0,25 $\mathrm{mL}$ de uma solução de dextran, marcado com tecnécio radioativo, em cada lado da região perianal em posição correspondente à direita e à esquerda, e obtenção de imagens por meio de uma gama câmara. Os resultados obtidos foram analisados aceitando-se um nível de significância de $95 \%(\mathrm{p}<0,05)$ mediante os seguintes modelos estatísticos: média aritmética e mediana, teste exato de Fisher, qui quadrado corri- 
gido para continuidade, de acordo com Yates e tabelas de distribuição do número de doentes.

RESULTADOS: Nos doentes com câncer retal, a progressão do marcador ocorre unilateralmente ou está ausente; nos outros, é bilateral e simétrica, embora possa haver retardo na progres- são. Testes estatísticos com alta significância mostraram que o índice de concordância entre o diagnóstico clínico e o resultado do exame linfocintilográfico é de 93,33\%.

CONCLUSÕES: A linfocintilografia é exame padronizado, exequiível em todos os casos indicados, indolor e inócuo; a linfocintilografia diferencia portadores de câncer do reto dos de outras afecções colo-proctológicas estudadas.

DESCRITORES: Linfocintilografia. Câncer retal. Linfonodos. Estadiamento do câncer retal.

\section{REFERENCES}

1. SHERMAN AI \& TER-POGOSSIAN M - Lymph-node concentration of radioactive colloidal gold following interstitial injection. Cancer 1953;6:1238-40.

2. HARPER PV, LATHROP KA \& JIMINEZ F - Technetium-99m as a scanning agent. Radiology 1965;85:101-8.

3. EGE GN - Internal mammary lymphoscintigraphy. Radiology 1976;118:101-7.

4. EGE GN \& CUMMINGS BJ - Interstitial radiocolloid iliopelvic lymphoscintigraphy: technique, anatomy and clinical application. Int J Radiation Oncology Biol Phys 1980;6:1483-90.

5. HENZE E, ROBINSON GD, KUHL DE et al. - Tc-99m dextran: A new blood-pool-labeling agent for radionuclide angiocardiography. J Nucl Med 1982a;23:348-53.

6. HENZE E, SCHELBERT HR, COLLINS JD et al. Lymphoscintigraphy with Tc-99m-labeled dextran. J Nucl Med 1982b;23: 923-9.

7. REASBECK PG, MANKTELOW A, MCARTHUR AM et al. - An evaluation of pelvic lymphoscintigraphy in the staging of colorectal carcinoma. Br J Surg 1984;71:936-40.

8. BUCCI L, SALFI R, MERAVIGLIA $F$ et al. - Rectal lymphoscintigraphy - Dis Colon Rectum 1984;27:370-5.

9. CASTRO SF, LIMA JMP, BOTELHO J et al. - Linfografia Cintigráfica em patologia ano-rectal. J Soc Ciên Méd Lisboa 1986;40:74-80.

10. FEIGEN M, CROCKER EF, READ J et al. - The value of lymphoscintigraphy, lymphangiography and computer tomography scanning in the preoperative assessment of lymph nodes involved by pelvic malignant conditions. Surg Gynecol \& Obstet 1987; 165:107-10

11. ACCARPIO G, SCOPINARO G, CLAUDIANI F et al. - Experience with local rectal cancer excision in light of two recent preoperative diagnostic methods. Dis Colon Rectum 1987;30:296-8.

12. KANAEV SV, METELEV VV, BYKOV AS et al. Diagnostic significance of lymphoscintigraphy in cancer of the rectum. Vopr Onkol 1988:34:814-9.

13. BYKOV AS \& METELEV VV - Intravital study of lymph outflow in rectal cancer. Vopr Onkol 1989;35:1059-62.

14. ARNAUD JP, BERGAMMASCHI R, SCHLOEGEL M et al. - Progress in the assessment of lymphatic spread in rectal cancer: rectal endoscopic lymphoscintigraphy. Dis Colon Rectum 1990a;33:398401 .
15. ASTLER VB \& COLLER FA - The prognostic significance of direct extension of carcinoma of the colon and rectum. Ann Surg 1954:139:846-52.

16. BRUMINI R - Câncer no Brasil. Dados histopatológicos 1976-1980. Rio de Janeiro. Ministério da Saúde, 1982. p 37-39.

17. BORING CC, SQUIRES TS \& TONG T - Cancer statistics. CA Cancer J Clin 1991;41:19-51.

18. GOLIGHER JC - Surgery of the anus, rectum and colon. $5^{\text {th }}$ ed London, Baillière Tindall, 1984. p 429.

19. TSYB AF, BERDOV BA, TLEPSHUKOV GK et al. - The role of lymphography in the choice and planning of treatment in patients with malignant tumors of the lesser pelvis. Vopr Onkol 1987;33:32-

20. MOSKOVIC E, FERNANDO I, BLAKE P et al. - Lymphography current role in oncology. Br J Radiol 1991:64:422-7.

21. DRINKWATER JR DC, WITTNICH C, BETHUNE DC et al. Endoscopic gastrointestinal lymphoscintigraphy. Curr Surg 1981;38:67-71

22. OSBORNE MP, PAYNE JH, RICHARDSON VJ et al. - The preoperative detection of axillary lymph node metastases in breast cancer by isotope imaging. Br J Surg 1983;70:1141-4.

23. HIMAL HS - Colorectal lymphoscintigraphy: a preliminary report. Gastrointest Endosc 1984;30:260-2.

24. CROLL MN, BRADY LW \& DADPARVAR S - Implications of lymphoscintigraphy in oncologic practice: principles and differences vis-a-vis other imaging modalities. Sem Nucl Med 1983;13:4-8

25. OSBORNE MP, JEYASINGH K, JEWKES RF et al. - The preoperative detection of internal mammary lymph node metastases in breast cancer. Br J Surg 1979;66:813-8.

26. STIBBE EP - The internal mammary lymphatic glands. J Anat 1918:52:257-64.

27. KAPLAN WD - Iliopelvic lymphoscintigraphy. Sem Nucl Med 1983;13:42-53

28. ARNAUD JP, GAVIOLI M, ADLOF M et al. - Un passo avanti nella valutazione ell'estensione lymphonodale del cancro del retto: la linfoscintigrafia rettale endoscopica. Minerva Chir 1990b 45:13740. 